\title{
Self-efficacy and performance of the roundhouse kick in taekwondo
}

\author{
Isaac ESTEVAN*1, Octavio ÁLVAREZ², Coral FALCÓ ${ }^{1}$ \& Isabel CASTILLO² \\ 1 Department of Applied Sciences to Physical Activity and Management. Universidad Católica de \\ Valencia "San Vicente Mártir" (Spain) \\ ${ }^{2}$ Department of Social Psychology. Universitat de València (Spain)
}

Recepción: 30/03/2014; Aceptación: 11/07/2014; Publicación: 16/07/2014.

\begin{abstract}
Development of self-efficacy scales allows the analysis of athletes' perceptions and examination of the relationship between perception and performance. The aim of this paper was to: (1) develop a specific self-efficacy scale in a taekwondo task, the roundhouse kick, and (2) analyse the sport performance and its relationship with two self-efficacy scales (specific and general) outcomes according to the athletes' gender. Forty-three taekwondo athletes (33 male and 10 female) participated in this study. The Physical (PSE) and Specific (RKSES) self-efficacy scales were administered. Performance data (impact force and total response time) were acquired by athletes kicking twice to an instrumented target. Results showed that the specific self-efficacy scale has high reliability and is able to predict sport performance in males and females. Males had higher self-efficacy scores and also higher performance results than females. Females' taekwondo psychological training should be focus on improving their self-efficacy perception in order to increase their performance in the roundhouse kick. This specific self-efficacy scale for the taekwondo roundhouse kick offers empirical information to coaches, sport psychologists and researchers that allow them to predict athletes' sport performance in the roundhouse kick.
\end{abstract}

Keywords: Martial arts; combat sports; kick; specific self-efficacy; general self-efficacy; biomechanics.

\section{Autoeficacia y rendimiento en la patada circular de taekwondo}

\section{Resumen}

El desarrollo de escalas de autoeficacia permite el análisis de las percepciones de los deportistas y el examen de la relación entre dichas percepciones y el rendimiento. El objetivo de este estudio fue (1) desarrollar una escala específica de autoeficacia para una tarea de taekwondo, la patada circular, y (2) analizar el rendimiento deportivo y su relación con los resultados de dos escalas de autoeficacia (específica y general) en función del género de los deportistas. En el estudio participaron 43 taekwondistas (33 hombres y 10 mujeres). Se administraron las escalas de autoeficacia Física (PSE) y Específica (RKSES). Los datos de rendimiento (fuerza de impacto y tiempo total de respuesta) se obtuvieron mediante el golpeo de los deportistas a un objetivo instrumentado. Los resultados mostraron que la escala de autoeficacia específica tiene una mayor fiabilidad y puede predecir el rendimiento deportivo en hombres y mujeres. Los hombres obtuvieron puntuaciones de autoeficacia y rendimientos más altos que las mujeres. El entrenamiento psicológico de las mujeres debería enfocarse en mejorar su percepción de autoeficacia con el objeto de aumentar su rendimiento en la patada circular. Esta escala específica de autoeficacia para el taekwondo facilita información empírica a entrenadores, psicólogos deportivos e investigadores, que les puede

\section{Auto-eficácia e rendimento do chute circular do taekwondo}

\section{Resumo}

O desenvolvimento de escalas de auto-eficácia permite a análise das perceções dos atletas e o exame da relação entre as ditas perceções e o rendimento. 0 objetivo do estudo foi: (1) desenvolver uma escala específica de autoeficácia para uma técnica do taekwondo: o chute circular; e (2) analisar o rendimento desportivo e a sua relação com os resultados das duas escalas de auto-eficácia (específica e geral), em função do gênero dos atletas. Participaram neste estudo 43 taekwondistas (33 homens e 10 mulheres). Administraram-se as escalas de autoeficácia Física (PSE) e Específica (RKSES). Os dados de rendimento (força de impacto e tempo total de resposta) foram obtidos mediante o golpe dos esportistas a um objetivo instrumentado. Os resultados mostraram que a escala de auto-eficácia específica tem uma maior fiabilidade e pode prever o rendimento desportivo dos homens e mulheres. Os homens obtiveram pontuações de auto-eficácia e rendimentos mais altos do que as mulheres. 0 treino psicológico das mulheres deveria se focar em melhorar a sua perceção de auto-eficácia com o objetivo de aumentar o seu rendimento com o chute circular. Esta escala específica de auto-eficácia para o taekwondo facilita a informação empírica dos treinadores, psicólogos desportivos e investigadores,

\footnotetext{
* E-mail: isaac.estevan@ucv.es. Address: Department of Applied Sciences to Physical Activity and Management. Universidad Católica de Valencia “San Vicente Mártir”. C/ Virgen de la Soledad s/n. Torrent, 46900 (Spain).
} 
permitir predecir el rendimiento deportivo de los atletas en la patada circular.

Palabras clave: Artes marciales; deportes de combate; patada; autoeficacia específica; autoeficacia general; biomecánica. permitindo-lhes prever o rendimento desportivo dos atletas com o chute circular.

Palavras-chave: Artes marciais; desportos de combate; chute; auto-eficácia específica; auto-eficácia geral; biomecânica.

\section{1.- Introduction}

In sport, self-efficacy is one of the main psychological skills for success (Devenport, 2006). Perceived self-efficacy refers to an individual's beliefs about their ability to be successful in a task (Bandura, 1997), acquired from the following sources: past performance accomplishments, vicarious experiences, verbal persuasion, and physiological states (Feltz, Short, \& Sullivan, 2008). Self-efficacy has been pointed out because it has important effects on the pattern of beliefs and behaviors (Bandura, 2002). In athletic pursuits, producing an optimal performance requires different skills. One of these is a special psychological domain that allows athletes to develop psychological skills to help them manage difficult situations before, during and after competitions (Pelegrín \& Jara, 2009). Such a skill set has multiple implications in performance and sport practice such as to contribute to levels of participation, motivation, and adherence in a variety of tasks (Bandura, 1997); therefore, higher levels of self-efficacy can be considered beneficial for the objectives of the training program (Morales-Negron, 2008).

Among different methods of measuring self-efficacy are general scales, such as the Physical Self-Efficacy (PSE) Scale (Ryckman, Robbins, Thornton, \& Cantrell, 1982), and specific scales based on Bandura's recommendations (Bandura, 1997). Even perceived self-efficacy has been pointed out as a remarkable point for description and application in performance (Feltz et al., 2008), we could not find any self-efficacy studies on taekwondo or on the use of specific self-efficacy scales in the current literature on combat sports. A study that developed a combative self-efficacy scale including items for measuring martial arts skills (Morales-Negron, 2008) provided evidence about training that can contribute to the levels of self-efficacy among participants. Moreover, regarding studies that measured general self-efficacy - e.g., in karate (Yang \& Pargman, 1993) and boxing (Lane, 2002) -, results showed that it predicts successful performance in championships (using victories in combats). Global or general scales showed modest correlations between self-efficacy and performance, but have difficulties when they want to predict the variability of individual behaviour in different life contexts accurately (Bandura, 1997). Thus, the use of general scales to measure self-efficacy is considered to have poor predictive and explanatory value (Moritz, Feltz, Fahrbach, \& Mack, 2000).

Efficacy beliefs should be measured in terms of specific judgments of capability. These may vary across realms of activity and under different levels of task demand within a given activity domain. Self-efficacy must be contextualized and applied to an individual task so that it is much more effective in measuring personal beliefs than general scales on the three dimensions of strength, magnitude and generality. Strength refers to the degree of certainty that a person has about measuring every domain; magnitude refers to the number of domains used for measuring the task; and generality refers to the number of domains in different contexts where a person feels efficacy (Bandura, 1997).

Thus, some authors have stated that when complex tasks need to be analyzed, general or physical self-efficacy measures are not suitable (Hu, McAuley, \& Elavsky, 2005). In taekwondo, the roundhouse kick is a complex task and is the most frequent kick used in training and competitions (Estevan, Alvarez, Falco, Molina-García, \& Castillo, 2011; Menescardi et al., 2012). Performance in terms of the impact force and response time has usually been analyzed to measure kick performance (Estevan et al., 2011; Falco et al., 2009).

Taking this background into account, and following Bandura's recommendations, the aim of this study was to support coaches and sport psychologists by providing a tool that allows them to determine taekwondo athletes' self-efficacy beliefs and make more accurate judgments about specific tasks in this sport. Thus, this paper had two aims: 
(1) to develop a specific self-efficacy scale for the roundhouse kick in taekwondo, and

(2) to analyze the sport performance and its relationship with two self-efficacy scales (specific and general) outcomes according to the athletes' gender.

\section{Material and methods}

\subsection{Participants}

Forty-three taekwondo athletes (33 male and 10 female) participated in this study $(M=$ 24.4; $S D=5.4$ years). Mean body weight was $72.48 \mathrm{~kg}(S D=13.36)$ and mean height was $1.75 \mathrm{~m}(S D$ $=0.10$ ). All the athletes trained three hours per week and had a minimum of four years' experience in competitions $(M=10.89 ; S D=6.88$ years $)$.

\subsection{Specific self-efficacy scale development}

The development of the scale followed three steps (Loevinger, 1957): development of items with discriminative ability by experts, checking the content of the scale for consistency, and verification of convergent or external validity of results.

In the first phase, information about key variables of the roundhouse kick from mechanical (impact force and response time) and technique (body collocation, knee flexion, etc.) perspectives was collected (see Appendix 1).

In the second phase (semi-structured interview), a panel of experts was asked for specific examples of the mechanical and technique factors. If they failed to provide an example of any of the most common factors, they were asked to comment specifically on its importance. A focus group was then generated to form a consensus about the key factors of the roundhouse kick. Based on these key factors, a scale of 25 items was developed to assess the specific self-efficacy beliefs for the roundhouse kick (Roundhouse Kick Self-Efficacy Scale; RKSES).

Six experienced taekwondo athletes tested the RKSES as pilot participants, with the aim of detecting any problems associated with questionnaire completion. The final version consisted of 12 items: seven on execution technique, three that complement some of previous items and two generic items on taekwondo kicks (see Appendix 1). The final version was applied to the 43 taekwondo athletes.

\subsection{Procedure}

Participants completed both scales (specific and general) and were measured anthropometrically (execution distance and height of impact) for performance assessment. After an individual warm-up (30 min), every athlete was able to develop several kicks (3-5 trials) to familiarize with the data acquisition process. Each subject was instructed to kick the indicated area of the dummy (force platform), "as strong and fast as you can when the blue light signal changed to red". When they informed about being ready the procedure started. The time delay between the verbal signal ('Ready') and the LED (light-emitting diode) signal was randomized (0.99-10.99 s).

The taekwondo athletes completed two roundhouse kicks with the dominant lower limb (31 right-footed and 12 left-footed) being the rear limb from a distance $(M=1.01 ; S D=0.06 \mathrm{~m}$ ) equal to the lower limb length (Falco et al., 2009). This procedure was approved by the Ethics Committee of the University of Valencia (Spain). All participants voluntarily signed an informed consent form.

\subsection{Instrumentation}

Specific self-efficacy was measured using the 12-item RKSES developed for this study. It measures self-efficacy beliefs in the roundhouse kick in taekwondo using a Likert scale from 1 (not 
capable) to 5 (totally capable). Cronbach's alpha $(\alpha)$ coefficient was 0.90 ; it was not increased by the removal of any individual item.

General self-efficacy was measured using the 22-item PSE Scale (Ryckman et al., 1982) to determine athletes' beliefs about perceived physical ability and physical self-presentation confidence using a Likert scale from 1 (strongly disagree) to 6 (strongly agree). Internal consistency of this scale was $\alpha=0.73$.

Sport performance was measured by the impact force and total response time (combined reaction and execution time) in the roundhouse kick (Falco et al., 2009) to the chest. Performance was measured by a data acquisition system composed of a force platform (by nine piezoresistive pressure sensors (Flexiforce ${ }^{\circledR}$ A201 model by Tekscan Company Inc., South Boston, USA) positioned in series in groups of three in a triangular structure; this structure was chosen taking into consideration that the force of the kick would be distributed more homogeneously on the target area. The sensors were calibrated following the manufacturer's recommendations (three sensors by three sensors first and finally the nine sensors together) (Estevan et al., 2011). The calibrating process allowed us to adjust the sensitivity based on a known load that helped achieve the best resolution) and an LED, both located in a mannequin, a contact platform, a microcontroller and a PC. Reliability of this system was measured by Cronbach's alpha $(\alpha=0.99)$ and the sensitivity of the system was 22.2 Newtons.

\subsection{Statistical analysis}

Statistical analysis was carried out using SPSS 20.0 (IBM ${ }^{\circledR}$, Armonk, NY). A KolmogorovSmirnov test showed normal distribution of the data. Bivariate correlations among items of RKSES, the PSE Scale and sport performance were carried out. A linear regression analysis was computed to determine whether RKSES or PSE Scale items predicted performance in taekwondo $(p<0.05)$. Student's $t$-test was used to compare RKSES and PSE items and performance according to gender; to reduce the error accumulated (the type I error rate) the Bonferrini correction was applied ( $p \leq$ 0.013 ). Cohen's $d$ score was quantified to analyse the effect size, $d$ values higher than 0.8 indicate large and between 0.5 and 0.8 indicate moderate effects (Cohen, 1988). Pearson's correlation was used to determine the convergent validity of the RKSES, examining relationships between each item of the RKSES and PSE Scale.

\section{Results}

Convergent validity results showed positive and significant relationships in item $1(r=0.47$; $p=0.001)$, item $2(r=0.49 ; p=0.001)$, item $3(r=0.31 ; p=0.030)$, item $4(r=0.41 ; p=0.006)$, item $5(r=0.41 ; p=0.006)$, item $8(r=0.40 ; p=0.008)$, item $9(r=0.40 ; p=0.008)$, item $10(r=0.40 ; p=$ $0.008)$, item $11(r=0.35 ; p=0.023)$, and item $12(r=0.44 ; p=0.003)$.

Bivariate correlation between PSE and performance (impact force and total response time) did not show significant relationships. On the other hand, regression analysis showed that in males, item 6 ("raising flexed knee in the correct way") and item 7 ("controlling lower limb fall with flexed knee in the correct way") that aimed at measuring technical execution aspects in the RKSES together predicted $21 \%$ of the variance of impact force $\left(\mathrm{R}^{2}=0.21, F(2,32)=4.03, \beta=0.24 ; p=\right.$ 0.028), whereas in females, item 2 ("kicking from execution distance in good reaction time") predicted $56.6 \%$ of the variance of impact force $\left(\mathrm{R}^{2}=0.57, F(1,9)=10.39, \beta=0.75 ; p=0.012\right)$, and item 10 ("improving performance from execution distance in good total response time") predicted $68.6 \%$ of the variance of total response time $\left(\mathrm{R}^{2}=0.69, F(2,32)=17.48, \beta=-0.83 ; p=0.003\right)$; item 2 and item 10 aimed at measuring tactical and performance aspects.

Student's $t$-test showed that males scored higher than females in item $1(p=0.003)$, item 2 $(p=0.008)$, item $5(p=0.002)$, item $6(p=0.005)$, item $11(p=0.013)$ and item $12(p=0.011)$ of the RKSES (see Table 1) and in the PSE $(p=0.012)$, but significant differences did not appear in items 3 , $4,7,8,9$ and 10 of RKSES. Males also kicked in a lower total response time ( $p=0.013)$ and with higher impact force $(p=0.003)$ than females. 
Table 1. Descriptive data in specific self-efficacy and performance according to gender.

\begin{tabular}{|c|c|c|c|c|c|c|}
\hline & \multicolumn{2}{|c|}{ Males $(n=33)$} & \multicolumn{2}{|c|}{ Females $(n=10)$} & \multirow[b]{2}{*}{$\boldsymbol{t}$} & \multirow[b]{2}{*}{ d-value $95 \%$ CI [LL, UL] } \\
\hline & $M$ & $S D$ & $M$ & $S D$ & & \\
\hline Ae 1 & 3.79 & 0.93 & 2.80 & 0.63 & $3.14^{*}$ & $1.16,95 \%$ CI $[0.85-1.56]$ \\
\hline Ae 2 & 3.00 & 0.90 & 2.10 & 0.88 & $2.78^{*}$ & $1.03,95 \%$ CI $[0.72-1.57]$ \\
\hline Ae 3 & 3.61 & 0.97 & 3.00 & 0.82 & 1.80 & \\
\hline Ae 4 & 2.97 & 0.89 & 2.30 & 0.95 & 2.07 & \\
\hline Ae 5 & 3.88 & 0.86 & 2.80 & 1.14 & $3.23^{*}$ & $1.20,95 \%$ CI $[0.90-1.90]$ \\
\hline Ae 6 & 3.45 & 1.06 & 2.30 & 1.16 & $2.95^{*}$ & $1.09,95 \%$ CI $[0.73-1.81]$ \\
\hline Ae 7 & 3.58 & 0.71 & 3.00 & 0.94 & 2.08 & \\
\hline Ae 8 & 3.58 & 0.94 & 2.90 & 0.99 & 1.97 & \\
\hline Ae 9 & 3.58 & 0.90 & 3.00 & 0.67 & 2.19 & \\
\hline Ae 10 & 3.39 & 0.86 & 3.00 & 0.82 & 1.28 & \\
\hline Ae 11 & 3.70 & 0.85 & 2.90 & 0.88 & $2.59 *$ & $0.96,95 \%$ CI $[0.67-1.50]$ \\
\hline Ae 12 & 3.33 & 0.69 & 2.60 & 0.97 & $2.67^{*}$ & $0.16,95 \%$ CI $[-0.07-6.15]$ \\
\hline PSE & 82.09 & 10.81 & 71.80 & 11.20 & $2.62 *$ & $0.97,95 \%$ CI $[-2.72-7.91]$ \\
\hline $\mathrm{TT}(\mathrm{s})$ & 0.819 & 0.090 & 0.898 & 0.080 & $-2.53^{*}$ & $0.92,95 \%$ CI $[0.87-0.95]$ \\
\hline IF $(\mathrm{N})$ & 1277.0 & 504.1 & 882.8 & 262.8 & $3.26^{*}$ & $0.88,95 \%$ CI $[-171.10-163.76]$ \\
\hline
\end{tabular}

\section{Discussion}

This study had two aims: to develop a specific self-efficacy scale for the roundhouse kick, the most frequently used kick in training and competition in taekwondo, and to analyze the sport performance and its relationship with two self-efficacy scales (specific and general) outcomes according to the athletes' gender.

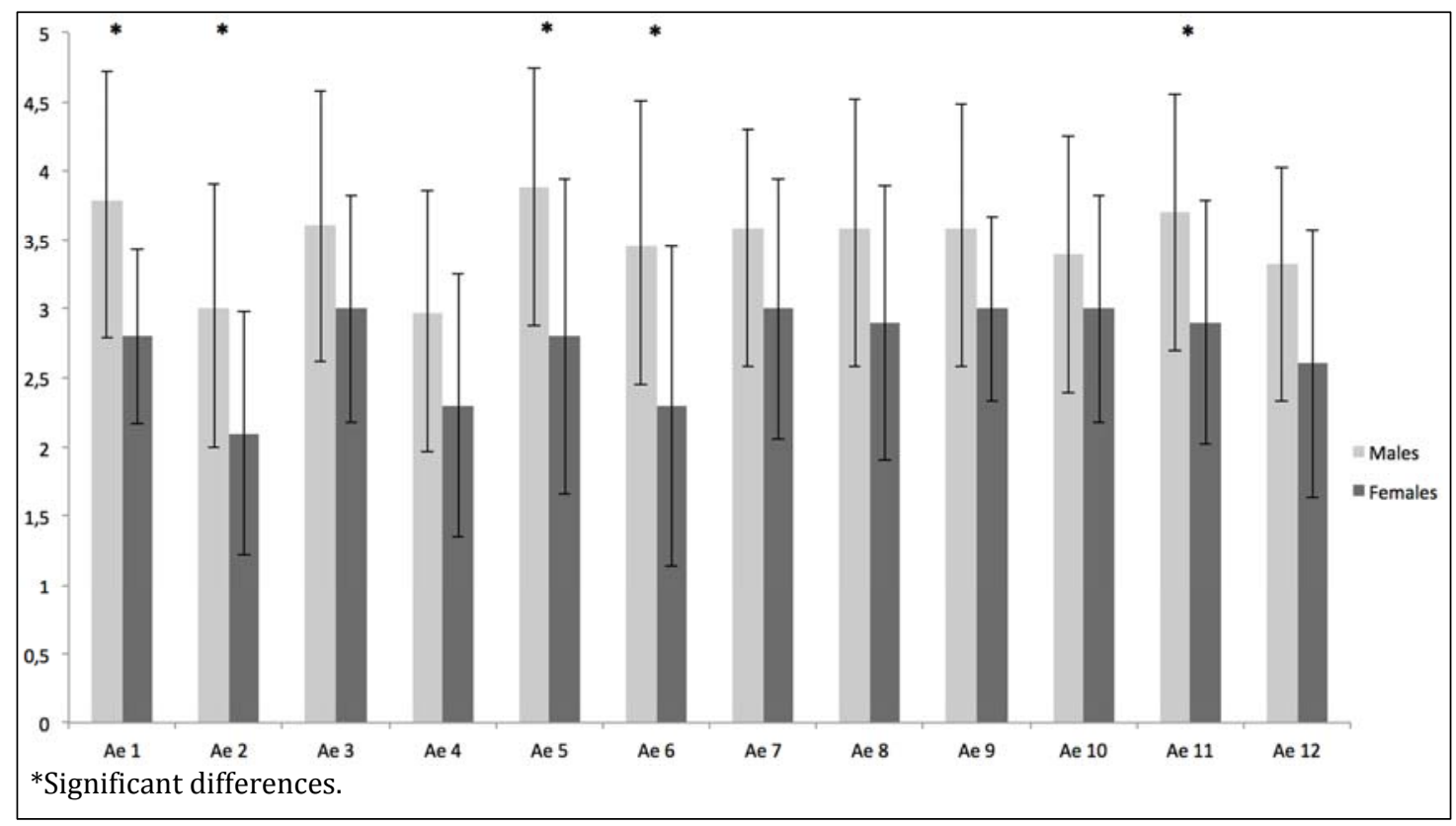

Figure 1. Results of specific self-efficacy scores (RKSES) by gender.

Measuring self-efficacy for this task (roundhouse kick) could provide information about how efficacious athletes feel when they kick (Morales-Negron, 2008). Comparative analysis by gender shows results in line with the literature in which males score higher than females (see figure 1) in the specific self-efficacy (Lázaro \& Villamarín, 1993), concretely in the items (items 1, 2, 5, 6 and 11) related to technical (stance position and knee flexion) and performance (execution and reaction time, and impact force) aspects. Our results (Cronbach's $\alpha$ values) suggest that the use of both scales is appropriate to measure self-efficacy, however the general self-efficacy scale (PSE) 
was not able to differentiate scores between males and females (see figure 2); only the specific scale RKSES has been able to discriminate results according to the gender. Moreover, the higher self-efficacy perception is accompanied by a males' higher performance in terms of lower total response time compared with females. With respect to effect size, as stated by Nakagawa and Cuthill (2007), when CI of the magnitude of the effect in a variable includes the zero value, significant differences should not be considered. In this study, this result has been obtained in item 12 (RKSES), in PSE and in the impact force scores, so suggestions regarding practical orientations in these variables must be caution. Then, when significant differences are found the effect size could be considered to be large (Cohen, 1988).Thus, in line with Bandura (1997), specific self-efficacy scales would be more appropriate than general self-efficacy scale allowing us to differentiate athletes' perception according to the gender and to predict efficacy perception of individual behavior in different life contexts, such as kicks, accurately.

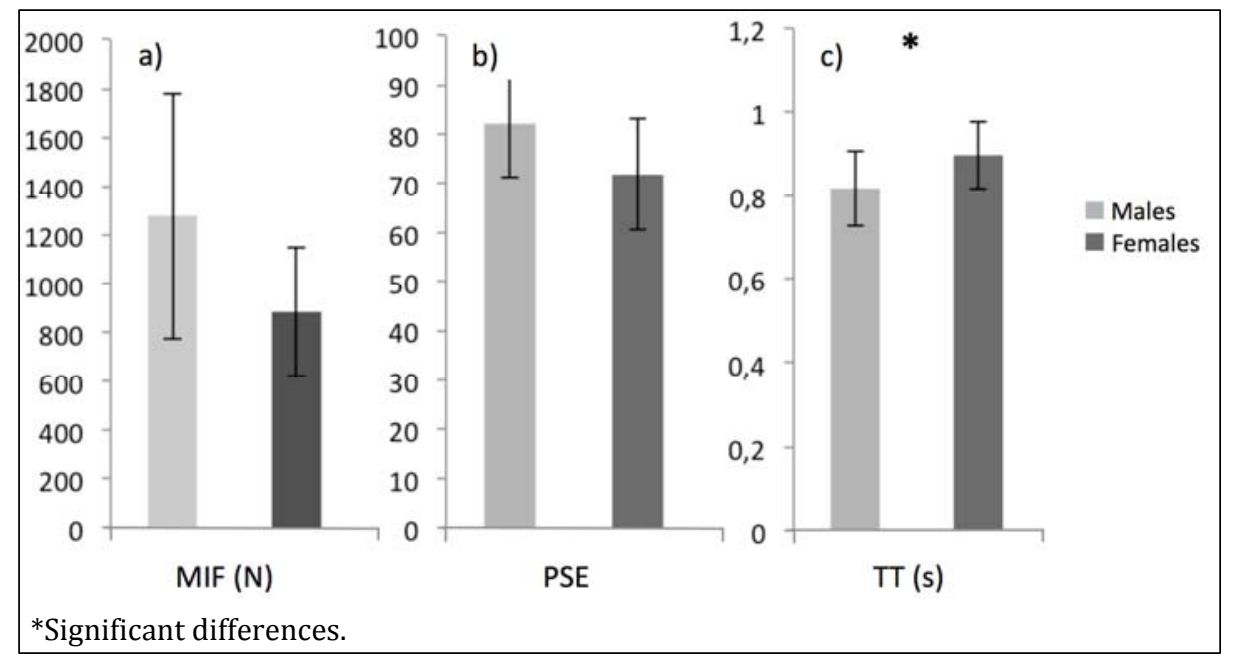

Figure 2. Results of Impact force in Newtons (a), general self-efficacy (PSE) with a range 0-96 (b), and total response time in seconds (c) by gender.

Regarding the relationship between self-efficacy and performance, the results seem to confirm the positive relation that Bandura (1997) stated. In our study, only specific self-efficacy predicted performance (impact force in the case of males, and impact force and total response time in the case of females), supporting Feltz's et al. (2008) orientations who stated that self-efficacy is related to performance in sport. This is also consistent with Lázaro and Villamarín's (1993) finding that specific self-efficacy for a task is a better predictor of individual performance than general selfefficacy. In this task, the RKSES items that predict variance provide information about how taekwondo athletes' key beliefs may be used to improve performance. The females' perceptions of their ability to kick from the execution distance in good response time (item 2) predicted the impact force positively what is supported by previous authors' suggestions (i.e., Falco, MolinaGarcía, Álvarez, \& Estevan, 2013) who stated that a higher capability to react to a stimulus could be related to a high impulse against the ground for kicking what could correspond with a high impact force. Also, females perceived options for improving the total response time (item 10) that negatively predicted total response time; that is, females seem to be able to perceive themselves capable to improve the performance in terms of total response time what corresponds in a high percentage with the reality in the roundhouse kick in taekwondo.

On the other hand, the males' perceptions of their ability to raise their flexed knee in the correct way (item 6) and control their lower limb fall with a flexed knee in the correct way (item 7) positively predicted impact force. These mentioned technical indicators allow us to explain an important percentage of the variance of the impact force. Thus, the practical implications of these results indicate the importance of training in key psychological factors to improve taekwondo athletes' performance. Since, if the male taekwondo athletes in this study want to improve impact force in the roundhouse kick, from a psychological perspective, training should focus on improving their self-efficacy for raising their flexed knee and controlling their lower limb fall, that is, it should 
focus on technical aspects by working on intensifying specific procedures in that area. The female taekwondo athletes should be trained in their self-perception of response time and ability to improve it by focus on execution and reaction time aspects.

This study also emphasizes the importance of objective measurement of dynamic (impact force) and kinematic variables (total response time) to provide empirical information in specific populations. In this sense, the small sample size could be noted as a limitation of our work. Nonetheless, Morales-Negron (2008) states that studies that analyse populations with specific characteristics, such as ours, should be accepted due to the accurate empirical information that could offer so that coaches base the males training orientations on, for instance, technical aspects when impact force would pretend to be improved. Moreover, in order to report more specific information that allow coaches and sport psychologists to orient appropriately the training future studies should analyze taekwondo athletes' self-efficacy perception according to the type of kick and/or tactical aspects and also considering the athletes' success in competition.

\section{Conclusion}

Females perceived capable to improve total response time explaining a high percentage of the mentioned performance variable. Furthermore, males kicked in a lower total response time than females. Thus, according to the results for males (in terms of their self-efficacy perception also predicted their performance), females' taekwondo psychological training should be focus on improving athletes' self-efficacy perception because it could help to increase their performance in the roundhouse kick.

In line with Bandura's recommendations (1997), the most appropriate method to predict performance in the roundhouse kick in taekwondo is using specific self-efficacy scales. This study contributes to the scientific knowledge of combat sports, particularly in taekwondo. Moreover, the results offer coaches and social psychology and sport researchers a reliable tool (RKSES) that is able to provide empirical information to allow the thorough analysis of athletes' specific selfefficacy in the roundhouse kick, and also contributes to the research and training context.

\section{Acknowledgements}

This research was supported by the Catholic University of Valencia (2011-007-002).

\section{References}

Bandura, A. (1997). Self-efficacy. The Exercise of Control. New York: Freeman and Company.

Bandura, A. (2002). Social cognitive theory in cultural context. Applied Psychology: An International Review, 51, 269-290.

Cohen, A. (1988). Statistical power analysis for the behavioural sciences (2nd ed.). Hillsdale, NJ: Lawrence Erlbaum.

Devenport, T. (1997) Perceptions of the contribution of psychology to success in elite kickboxing. Journal of Sports Sciences and Medicine, CSSI, 99-107.

Estevan, I., Alvarez, O., Falco, C., Molina-García, J., \& Castillo, I. (2011). Impact force and time analysis influenced by execution distance in a roundhouse kick to the head in taekwondo. Journal of Strength and Conditioning Research, 25, 2851-2856.

Falco, C., Alvarez, O., Castillo, I., Estevan, I., Martos, J., Mugarra, F., \& Iradi, A. (2009). Influence of the distance in roundhouse kick's execution time and impact force in Taekwondo. Journal of Biomechanics, 42, 242-248.

Falco, C., Molina-García, J., Álvarez, O., \& Estevan, I. (2013). Effects of target distance on select biomechanical parameters in taekwondo roundhouse kick. Sport Biomechanics, 12, 324-333.

Feltz, D. L., Short, S., \& Sullivan, P. (2008). Self Efficacy in Sport: Research and Strategies for Working with Athletes, Teams and Coaches. Champaign: Human Kinetics.

Hu, L., McAuley, E., \& Elavsky, S. (2005). Does the Physical Self-Efficacy Scale Assess Self-Efficacy or Self-Esteem? Journal of Sport and Exercise Psychology, 27, 152-170. 
Loevinger, J. (1957). Objective test as instruments of psychological theory. Psychological Reports, 3, 635-694.

Lázaro, I., \& Villamarín, F. (1993). Capacidad predictiva de la auto-eficacia individual y colectiva sobre el rendimiento en jugadoras de baloncesto [Predictive capacity of individual and collective self-efficacy in female basketball players' performance]. Revista de Psicología del Deporte, 4, 27-38.

Lane, A. M. (2002). Relationships between performance toward accomplishment and self-efficacy in amateur boxing. Perceptual and Motor Skills, 94, 1056.

Menescardi, C., Bermejo, J. L., Herrero, C., Estevan, I., Landeo, R., \& Falco, C. (2012). Diferencias técnico tácticas en taekwondistas universitarios según sexo y categoría de competición [Technical tactical differences among university level taekwondo competitors by gender and weight division]. Revista de Artes Marciales Asiáticas, 7(2), 1-11. Retrieved from http://revpubli.unileon.es/ojs/index.php/artesmarciales/article/view/82.

Morales-Negron, H. (2008). Self-efficacy and state anxiety during mandatory combatives training. Archives of Budo, 4, 26-31. Retrieved from http://www.archbudo.com/abstracted. php?level=5\&ICID=867239.

Moritz, S. E., Feltz, D. L., Fahrbach, K. R., \& Mack, D. E. (2000). The relation of self-efficacy measures to sport performance: A meta-analytic review. Research Quarterly of Exercise and Sport, 71, 280-294.

Nakagawa, S., \& Cuthill, I. C. (2007). Effect size, confidence interval and statistical significance: a practical guide for biologists. Biological Reviews, 82, 591-605.

Pelegrín, A., \& Jara, P. (2009). Manipulación de submodalidades de la representación mental en el trabajo psicológico con taekwondistas: una intervención en el marco de la P.N.L [Submodalities manipulation of the mental representation at psychological work with taekwondists: an intervention in the context of P.N.L.]. Cuadernos de Psicología del Deporte, 9, 39-51.

Ryckman, R. M., Robbins, M. A., Thornton, B., \& Cantrell, P. (1982). Development and Validation of a Physical Self-Efficacy Scale. Journal of Personality and Social Psychology, 42, 891-900.

Yang, G., \& Pargman, D. (1993). An investigation of relationship among sport-confidence, selfefficacy and competitive anxiety and their ability to predict performance on a karate skill test. In S. Serpa, J. Alves, V. Ferreira, \& A. Paula-Brito, (Eds.), Proceedings of the 8th World Congress of Sport Psychology (pp. 968-972), Lisboa, Portugal.

\section{Appendix 1. Roundhouse Kick Self-Efficacy Scale}

Indicate how capable you feel of completing the following actions:

\begin{tabular}{lllllll} 
& \multicolumn{1}{c}{$\begin{array}{c}\text { Not } \\
\text { capable }\end{array}$} & \multicolumn{3}{c}{$\begin{array}{c}\text { Totally } \\
\text { capable }\end{array}$} \\
\cline { 2 - 7 } 1. Kicking from execution distance with good execution time. & 0 & 1 & 2 & 3 & 4 & 5 \\
2. Kicking from execution distance with good reaction time. & 0 & 1 & 2 & 3 & 4 & 5 \\
3. Kicking from execution distance with sufficient impact force. & 0 & 1 & 2 & 3 & 4 & 5 \\
4. Executing the technique with the correct body allocation. & 0 & 1 & 2 & 3 & 4 & 5 \\
5. Getting into the correct body stance position to start the action. & 0 & 1 & 2 & 3 & 4 & 5 \\
6. Raising the flexed knee in the correct way. & 0 & 1 & 2 & 3 & 4 & 5 \\
7. Controlling lower limb fall with the flexed knee in the correct way. & 0 & 1 & 2 & 3 & 4 & 5 \\
8. Focusing on the kicking action. & 0 & 1 & 2 & 3 & 4 & 5 \\
9. Winning a golden point round in a contest. & 0 & 1 & 2 & 3 & 4 & 5 \\
10. Improving performance from execution distance with good total response & 0 & 1 & 2 & 3 & 4 & 5 \\
time. & 0 & 1 & 2 & 3 & 4 & 5 \\
11. Kicking from execution distance with high impact force. & 0 & 1 & 2 & 3 & 4 & 5 \\
12. Kicking efficiently (with high impact force and low total response time).
\end{tabular}




\section{Authors' biographical data}

Isaac Estevan (PhD), associate professor at the Catholic University of Valencia "San Vicente Mártir". He is the director of the Department of Applied Sciences to Physical Activity and Management in the mentioned University. He is author and coauthor in several national and international impact journals in the Biomechanics and Sport Sciences fields. Also, he is a taekwondo technical assessor in the Spanish University Sport Comittee. Before his current position he was a taekwondo trainer at the University of Valencia. As an athlete was a member in the Spanish National Team at senior and university level (2004-2008). E-mail: isaac.estevan@ucv.es.

Octavio Álvarez (PhD) is an adjunct professor at the University of Valencia. He is author and coauthor in several national and international impact journals in the Social Psychology and Sport Sciences field. His experience in peak performance is as a consultant in sport psychology, and as a sport psychologist working for organizations of the Spanish government and Competition Services of the University of Valencia (Spain). He has worked as sport psychologist in sports such as: athletics, combat sports, gymnastics, tennis and soccer. The athletes' levels he works with are European, American and World Championships, Olympic Games and Paralympics`. E-mail: octavio.alvarez@uv.es.

Coral Falcó (PhD) she is author and coauthor in several national and international impact journals in the Biomechanics and Sport Sciences fields. Also, as an athlete was a member in the Spanish National Team at senior level (1994-1997) being World Cup and European Champion in combat and technique championships, respectively. Moreover, she was the main trainer of the taekwondo team of the University of Valencia (20032008) and also she was a coach of the Spanish National Team (2004). E-mail: coral.falco@ucv.es.

Isabel Castillo ( $\mathrm{PhD}$ ) is an associate professor at the University of Valencia. She is author and coauthor in more than forty international impact journals in the Social Psychology field. Some of the published articles are related to the combat sports field which are based on the framework of the Self-Determination Theory. She is an honorable partner in the PAPA project (http://www.projectpapa.org/) to enhancing young peoples' health and well-being through positive experiences in sport, supported by the European Commission (FP7 Health). E-mail: isabel.castillo@uv.es. 